\title{
Obituaries
}

\section{Sir Donald Harrison}

Pioneer ear, nose, and throat surgeon, for many years Britain's only professor of otolaryngology, and a campaigner against chewing tobacco and unnecessary tonsillectomy

Sir Donald Harrison was one of the leading ear, nose, and throat surgeons of his day. He specialised in difficult cancer cases and devised a "pull up" operation that allowed many patients who had had their voice boxes removed to develop a usable, though hoarse, voice. He was also an expert on the comparative anatomy of the voice boxes of mammals.

Harrison was a house surgeon at Guy's and then at the Royal Gwent Hospital in Newport. As a registrar at the Shrewsbury Eye and Ear Hospital he saw a five year old child bleed extensively after a tonsil operation. The hospital had no blood bank and so the patient was transported 15 miles to the nearest large hospital, but was dead on arrival. After that, Harrison campaigned for a government inquiry into the risks of tonsillectomy. He was also one of the band of leading doctors who warned the public about the dangers of chewing tobacco, which led the British government to ban the sale of a product called Skoal Bandits.

In 1962 he was appointed as consultant surgeon at the Royal National Ear, Nose and Throat Hospital in London, and a year later was appointed professor at its associated academic institution, the Institute of Laryngology and Otology. For many years he was Britain's only professor in the specialty. He held these appointments until his retirement in 1990, having spent the final year as dean. In 1990 he was knighted for services to ear, nose, and throat surgery. He was

\section{Stanley Dillon}

Former general practitioner Rugeley, Staffordshire (b Burslem 1915; q Birmingham 1940), d 12 February 2003.

After qualifying with a gold medal in surgery, he worked at the wartime emergency medical services hospital in Bromsgrove before serving at a naval base in Ceylon. In Rugeley in the early 1950s he helped establish a large group practice. He was awarded the Charles Oliver Hawthorne Prize (BMA) in 1970 for "A study of congenital defects in a practice population." After retirement he returned to part time work in a Stafford practice. In retirement he

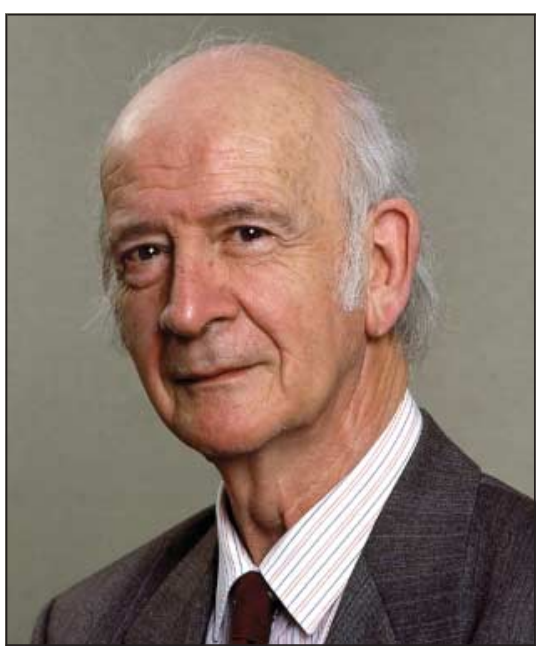

given the title of emeritus surgeon to Moorfields Eye Hospital in 1991.

Harrison had a lifelong interest in the voice boxes of mammals, and had an animal pathology collection that included specimens from London Zoo's most famous gorilla, Guy, and elephants, polar bears, penguins, and bats (which are especially interesting as they use echolocation).

$\mathrm{He}$ had many papers published in learned journals, especially on cancer surgery, and wrote or coedited several books, including The Anatomy and Physiology of the Mammalian Larynx, Tumours of the

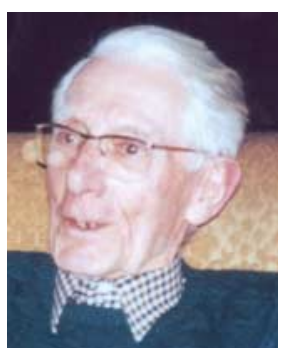

indulged his love of the countryside. Predeceased by his wife and two daughters, he leaves a son and four grandchildren. [Roger Dillon]
Upper Jaw, and Felix Semon (1849-1921): a Victorian Laryngologist. He also wrote chapters in textbooks on general and ear, nose, and throat surgery.

An examiner for universities in Britain, Australia, and Hong Kong, he was on the editorial board of several learned journals, and was an honorary member of otolaryngology societies in Australia, Denmark, Egypt, France, Hong Kong, Jamaica, the Philippines, Poland, Spain, Yugoslavia, and the United States.

A brilliant speaker who didn't use notes, he was invited to speak in many countries, giving many of the prestigious medical lectures of the English-speaking world. $\mathrm{He}$ also gave talks on Richard III and the princes in the Tower, one of his many interests. His forensic knowledge led to his conviction that one of the jaw bones in the Tower was not authentic, while the other was, showing traces of hereditary disease.

When his wife died in 2000 he took up gourmet cooking. He leaves two daughters. [Caroline Richmond]

Sir Donald Frederick Norris Harrison, ear, nose, and throat surgeon Royal National Throat, Nose and Ear Hospital 1962-90 and professor of laryngology and otology University of London 1963-90 and dean, 1989-90, Institute of Laryngology and Otology, Gray's Inn Road (b 1925; q Guy's Hospital, London, 1948; MS, $M D, F R C S, F R C O p h t h)$, died from bowel cancer on 12 April 2003.

\section{Eric Ronald Down}

General practitioner Northwich, Cheshire, 1983-2003 (b Dulwich, London, 1952; $q$ Manchester 1976), died from pulmonary embolus on 24 February 2003.

Eric came from humble beginnings in London to gain entry to medical school. He joined the Royal Air Force as an undergraduate and after qualification served five years as a medical officer at various airbases in England. He left the air force as a squad-

Longer versions of these obituaries are available on bmj.com 
ron leader and entered general practice in Cheshire. Eric was naturally gregarious and had a memorable and infectious laugh. In his latter years he was troubled by bouts of increasingly resistant depression, limiting his ability to work. He leaves a wife, Elizabeth, and two daughters. [DEEPAK Kalra, Bill Forsyth]

B+

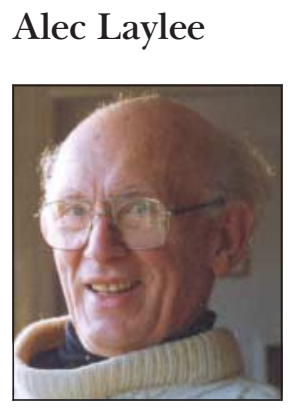

Former occupational health doctor Dorset (b 1922; q Liverpool 1952), d 6 April 2003.

Alec served in the Royal Navy from 1941 until hostilities ceased. He took part in the Salerno landings, numerous Russian arctic convoys, and the D Day landings, and was mentioned in dispatches. He took up medicine after the war, had various hospital appointments in Liverpool, and then became first medical officer at the Atomic Energy Establishment, Winfrith. He worked in diabetic clinics at Weymouth, Dorchester, and Bridport, and actively promoted the diabetes service until his full retirement in January 1987. He was a competitive swimmer and maintained an international ranking into his $70 \mathrm{~s}$. Predeceased by his wife, Edna, he leaves two children and two grandchildren. [DAvid Cove]

p+

\section{James Fleming McHarg}

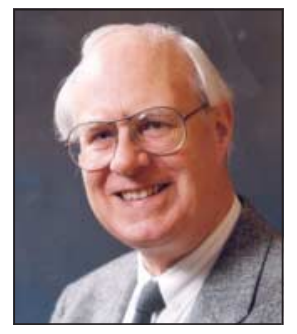

Former consultant psychiatrist and honorary senior lecturer Dundee (b 1917; q Edinburgh 1940; MD, FRCP Ed, FRCPsych), died from endocarditis on 10 March 2003.

James McHarg's medical career began in the Royal Navy, where he achieved the rank of surgeon commander. In civilian life he trained at the Royal Edinburgh Hospital, and thence moved to Gartnavel Royal Hospital in Glasgow as deputy physician superintendent before coming to his final post in Dundee. His special clinical interests included neuropsychiatric syndromes, affective disorder in children (he published a valuable paper on childhood mania), and Jungian psychopathology. Jungian concepts led him to a close study of cases of paranormal phenomena. [Peter Aungle]

\section{Charles Douglas Needham}

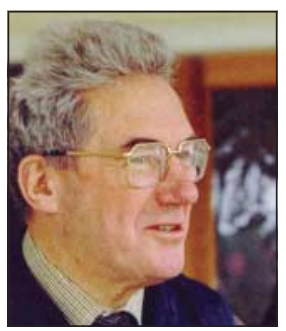

Former consultant physician Aberdeen (b 1915; q Middlesex Hospital, London, 1939; MD, FRCP), $d 7$ June 2003.

After working in Aberdeen as a registrar, Douglas Needham served in the Royal Army Medical Corps in northwest Europe and India. He was appointed consultant physician in Aberdeen in 1948. He assembled a substantial practice in gastroenterology, which soon showed the need for a specialist appointment and, over time, he saw the emergence of the present fourconsultant unit. Early on Douglas revealed the potential of clinical audit in his community based studies of alimentary tract haemorrhage, published in 1950 and in 1973, and of colorectal cancer in 1980. He leaves a wife, Margaret; three children; and four grandchildren. [Peter F Jones]

\section{Suli ("Pat") Patel}

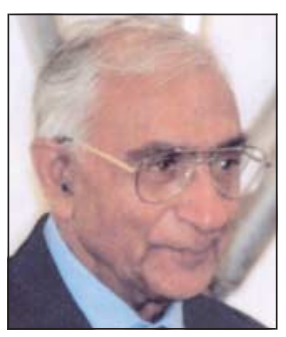

Former general practitioner south London (b Pretoria 1919; q Sheffield University 1946), died from thyroid cancer on 10 May 2003. As a second class citizen in Johannesburg, Suli was taught at the Christian Brothers of the Resurrection by, among others, the antiapartheid campaigner Archbishop Trevor Huddleston. He met and married Mima, who qualified at Sheffield in 1949, and after house jobs, including anatomy demonstrating, he served in the Pakistan Army Medical Corps as a graded surgeon for five years. On return to England with a young family, Suli and Mima settled into general practice in south London. His whole life was centred around his four children and seven grandchildren and his home was always filled with family and friends. [ANDY ANDERson]

\section{Ernest Herman Rainer}

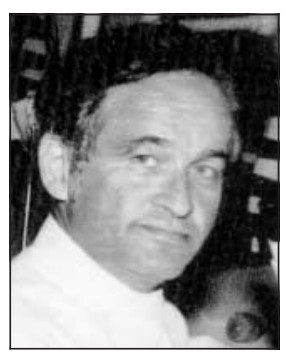

Former consultant ear, nose, and throat surgeon Dartford and Sevenoaks Hospitals, Kent (b Germany 1916; q Edinburgh 1941; FRCS Ed), d 11 Apri1 2003.

The son of a Dusseldorf businessman, he came from Germany in 1936 to study medicine at Edinburgh University. Following the outbreak of the second world war he was, as an "alien," interned in Canada, but returned to complete his qualifications at Edinburgh and Glasgow. He then joined the Royal Army Medical Corps, where he served as a captain until the end of the war. Ernest had a wide experience in all branches of otolaryngology, mainly otology and neck surgery. He was an accomplished violinist and played in several local orchestras and music groups. He leaves two daughters and four grandchildren. [NICKY ASHFORD]

\section{An apology \\ Obituary of David Horrobin}

A complaint was made to the Press Complaints Commission about our obituary of David Horrobin (BMJ 2003;326:885; see also $B M J$ 2003;326:1088-9 and 1091). During the discussions that surrounded the complaint we decided that we should apologise to the family for the distress we had caused. The commission took the complaint to adjudication and judged that no further action was required.

We recognise that the obituary caused offence and upset to Dr Horrobin's family, friends, and colleagues at a sensitive time. This was not our intention; our intention was to publish a balanced obituary that fairly encompassed both the positive and negative aspects of its subject's life. Nevertheless, we recognise that the manner in which we executed our attempt to achieve this may have lacked sensitivity. Accordingly, we regret that Dr Horrobin's family and friends have been caused distress and we apologise to them for it.

The full judgment of the Press Complaints Commission will be available shortly on the commission's website (www.pcc.org.uk). 